\title{
PLAGUE, QUARANTINES AND GEOPOLITICS IN THE OTTOMAN EMPIRE
}





\title{
PLAGUE, QUARANTINES
} AND GEOPOLITICS IN THE OTTOMAN EMPIRE

\author{
$++$ \\ BİRSEN BULMUŞ
}

EDINBURGH

University Press 
For my mother, Beyaz Bulmuş and my late father, Ahmet Bulmuş

(C) Birsen Bulmuş, 2012

Edinburgh University Press Ltd

22 George Square, Edinburgh EH8 9LF

www.euppublishing.com

Typeset in JaghbUni Regular by

Servis Filmsetting Ltd, Stockport, Cheshire, and

printed and bound in Great Britain by CPI Group (UK) Ltd, Croydon CR0 4YY

A CIP record for this book is available from the British Library

ISBN 9780748646593 (hardback)

ISBN 9780748646609 (webready PDF)

ISBN 9780748655472 (epub)

ISBN 9780748655465 (Amazon ebook)

The right of Birsen Bulmuş to be identified as author of this work has been asserted in accordance with the Copyright, Designs and Patents Act 1988. 